\title{
PERAN SERTA MASYARAKAT DALAM PENGELOLAAN RUANG TERBUKA HIJAU (RTH) DI KOTA BANDUNG
}

\author{
Nadia Astriani \\ email: nadia.astriani@unpad.ac.id
}

\begin{abstract}
As a vehicle for social interaction, open spaces are expected to be able to link all of members of society (or the local community) without differentiating between their social, economic and cultural background. Green open space forms part of the urban space available in a region that has been filled with plants in order to bring ecological, social, cultural and aesthetic benefits. From the research conducted previously, it may be gathered that reaching the green open space proportion of $30 \%$ in the city region could only have been accomplished by involving many stakesholders, especially the local community members. This phenomenon piqued the interest of the researchers to conduct further research into the active participation of society (local community members) in the management of green open space and into the policies issued by the government to increase this effort. The outcome shows that the active participation of the local community members in the utilization of green open space serves not only to supervise the government policies, but it also plays an important role in managing and maintaining the green open space in their neighborhood. The expansion of the local community's grasp of the concept being not only the party affected by its impact, but also as the interest and pressure group broadening its active participation by participating in managing the green open space, and even expanding the green open space by making agreements with the government. On the other hand, the government itself has been making various efforts to increase the active participation from society by encouraging the usage of Corporate Social Responsibility to manage the green open space and offer training sessions and courses to the local community involved.
\end{abstract}

Keywords:

Spatial Planning, Green Open Space, Community Participation

\begin{abstract}
Abstrak
Ruang terbuka, sebagai wahana interaksi sosial diharapkan dapat mempertautkan seluruh anggota masyarakat tanpa membedakan latar belakang sosial, ekonomi, dan budaya. Ruang terbuka hijau adalah bagian dari ruang terbuka suatu kawasan perkotaan yang diisi oleh tumbuhan dan tanaman guna mendukung manfaat ekologi, sosial, budaya, ekonomi dan estetika. Dari beberapa penelitian yang telah dilakukan terlebih dahulu, diketahui bahwa pemenuhan proporsi Ruang Terbuka Hijau sebesar 30\% di kawasan perkotaan, hanya dapat dilakukan dengan melibatkan berbagai stakesholder, terutama masyarakat. Hal ini menyebabkan peneliti tertarik untuk meneliti lebih jauh mengenai bentuk peran serta masyarakat dalam pengelolaan ruang terbuka hijau dan kebijakan yang dikeluarkan pemerintah untuk mendorong peran serta masyarakat dalam pengelolaan Ruang Terbuka Hijau. Hasil penelitian menunjukkan peran serta masyarakat dalam pemanfaatan Ruang Terbuka Hijau tidak lagi hanya sekedar mengawasi kebijakan pemerintah, tapi berperan aktif dalam menata dan merawat Ruang Terbuka Hijau yang ada di lingkungannya. Perluasan pengertian masyarakat yang tidak semata-mata pihak yang terkena dampak, tapi juga sebagai kelompok interest dan pressure group membuat peran serta semakin luas dengan ikut melakukan pengelolaan bahkan penambahan Ruang Terbuka Hijau melalui perjanjian dengan pemerintah. Di sisi lain pemerintah melakukan berbagai cara untuk meningkatkan peran serta masyarakat dengan mendorong penggunaan CSR untuk mengelola RTH dan memberikan pelatihan-pelatihan kepada masyarakat.
\end{abstract}

Kata Kunci:

Penataan Ruang, Ruang Terbuka Hijau, Partisipasi Masyarakat 


\section{Pendahuluan}

Ruang terbuka, dalam Peraturan Menteri Nomor 5 Tahun 2008, didefinisikan sebagai ruang-ruang dalam kota atau wilayah yang lebih luas, baik dalam bentuk area/kawasan, maupun dalam bentuk area memanjang/jalur, di mana penggunaannya lebih bersifat terbuka yang pada dasarnya tanpa bangunan. Berdasarkan tutupan lahan dan fungsinya, ruang terbuka dapat diklasifikasikan menjadi 2 (dua) jenis, yaitu ${ }^{1}$ :

1. Ruang Terbuka Hijau (RTH), yaitu area memanjang (jalur) dan/atau mengelompok, yang penggunaannya lebih bersifat terbuka, tempat tumbuh tanaman, baik yang tumbuh tanaman secara alamiah, maupun yang secara sengaja ditanam.

2. Ruang Terbuka Non Hijau (RTNH), yaitu ruang terbuka di wilayah perkotaan yang tidak termasuk dalam kategori RTH, dengan tutupan lahan yang didominasi oleh lahan yang diperkeras maupun badan air.

Ruang terbuka menciptakan karakter masyarakat kota. Sebagai wahana interaksi sosial, ruang terbuka diharapkan dapat mempertautkan seluruh anggota masyarakat tanpa membedakan latar belakang sosial, ekonomi, dan budaya.

Pentingnya peran Ruang Terbuka Hijau terlihat dari kewajiban ketersediaan Ruang Terbuka Hijau di suatu wilayah. Proporsi ruang terbuka hijau pada wilayah kota paling sedikit 30\% dari luas wilayah kota, terdiri dari ruang terbuka hijau publik sebesar $20 \%$ dan sisanya merupakan ruang terbuka hijau privat. Pengelolaan RTH merupakan bagian yang tidak terpisahkan dari dokumen perencanaan penataan ruang daerah, dengan ruang lingkup mencakup perencanaan pemanfaatan $\mathrm{RTH}$, pelaksanaan, pengawasan, pengendalian, dan evaluasi.

Peran serta masyarakat dalam pengelolaan Ruang Terbuka Hijau merupakan salah satu faktor penting guna mengeliminasi, setidaknya mengurangi potensi timbulnya konflik kepentingan dalam pemanfaatan ruang. Tujuan akhir

1 BAPPEDA, Laporan Master Plan Ruang Terbuka Hijau Kota Bandung 2012-2032, hlm. 2-20, Bandung 
penataan ruang, baik RTRW maupun RTR Kawasan dan RRTR adalah untuk kepentingan seluruh lapisan masyarakat. Lebih lanjut Hardjasoemantri mengatakan apabila tindakan-tindakan diambil untuk kepentingan masyarakat dan apabila masyarakat diharapkan untuk menerima dan patuh pada tindakan tersebut, maka masyarakat harus diberi kesempatan untuk mengembangkan dan mengutarakan pendapatnya ${ }^{2}$.

Melihat fungsi dari ruang terbuka hijau, maka pengelolaannya tidak dapat dipisahkan dari masyarakat. Hal ini menghasilkan pertanyaan bagaimana bentuk peran serta masyarakat dalam pengelolaan ruang terbuka hijau di kota Bandung?; dan bagaimana upaya pemerintah dalam mendorong peran serta masyarakat dalam pengelolaan Ruang Terbuka Hijau?

\section{Pembahasan}

Kota merupakan lambang peradaban kehidupan manusia, tempat pertumbuhan ekonomi, sumber inovasi dan kreasi, pusat kebudayaan dan wahana untuk peningkatan kualitas hidup 3 . Janice Perlman, pengarang dan pendiri dari Proyek Mega-Kota, mengatakan:

"Dunia ini akan lebih didominasi oleh kota. Pada tahun 1800, hanya 3\% dari populasi dunia tinggal di area kota. Pada 1950 angkanya menjadi $29 \%$ dan segera setelah tahun 2000 , lebih dari 50\% orang akan tinggal di kota-kota."

Kondisi tersebut dapat dirasakan saat ini, dimana kota menanggung beban teramat berat bagi penduduk kotanya. Permasalahan kota yang sangat komplek, menimbulkan gagasan pembentukan kota berkelanjutan, yaitu kota yang dalam perkembangan dan pembangunannya mampu memenuhi kebutuhan masyarakat masa kini, mampu berkompetisi dalam ekonomi global dengan mempertahankan keserasian lingkungan, vitalitas sosial, budaya, politik dan pertahanan

\footnotetext{
${ }^{2}$ A.M. Yunus Wahid, 2014, Pengantar Hukum Tata Ruang, Prenadamedia Group, Jakarta, hlm. 221.

${ }^{3}$ Eko Budihardjo dan Djoko Sujarto, Kota Berkelanjutan, PT. ALUMNI, Bandung, hlm. 21.
} 
keamanannya, tanpa mengabaikan atau mengurangi kemampuan generasi mendatang dalam pemenuhan kebutuhan mereka ${ }^{4}$.

Pendekatan pembangunan kota berkelanjutan (kota hijau) harus dilaksanakan dengan mengombinasikan pertumbuhan ekonomi yang sehat dan ramah lingkungan (pro green growth), meningkatkan kesejahteraan masyarakat (pro poor), menyediakan lapangan kerja yang ramah lingkungan (pro green job) dan dalam bingkai menjaga kelestarian lingkungan (pro environment). Membangun kota hijau dilakukan dengan mengoptimalkan sumber daya manusia, teknologi dan jasa ekosistem yang memungkinkan kota dikelola secara cerdas dan berlanjut. ${ }^{5}$

Ruang tidak dapat dipisahkan dari manusia baik secara psikologis, emosional ataupun dimensional. Manusia berada dalam ruang, bergerak, menghayati, dan berpikir, juga membuat ruang untuk menciptakan dunianya. Sampai saat ini pemanfaatan ruang masih belum sesuai dengan harapan yakni terwujudnya ruang yang nyaman, produktif dan berkelanjutan. Menurunnya kualitas permukiman di perkotaan bisa dilihat dari kemacetan yang semakin parah, berkembangnya kawasan kumuh yang rentan dengan bencana banjir/longsor serta semakin hilangnya ruang terbuka (open space) untuk artikulasi dan kesehatan masyarakat. Tanpa ruang-ruang publik masyarakat, yang terbentuk adalah masyarakat maverick yang non konformis-individualis-asosial, yang anggota-anggotanya tidak mampu berinteraksi apalagi bekerja sama satu sama lain.

Ruang Terbuka Hijau (RTH) kota adalah bagian dari ruang-ruang terbuka suatu wilayah perkotaan yang diisi oleh tumbuhan, tanaman, dan vegetasi (endemik, introduksi) guna manfaat langsung dan/atau tidak langsung yang dihasilkan oleh RTH dalam kota tersebut yaitu keamanan, kenyamanan, kesejahteraan, dan keindahan wilayah perkotaan tersebut. Penyediaan RTH kawasan perkotaan dapat dilakukan berdasarkan perhitungan

\footnotetext{
${ }^{4}$ Id., hlm. 22 dan 27.

${ }^{5}$ Nirwono Joga, Gerakan Kota Hijau, PT. Gramedia Pustaka Utama, 2013, hlm. 3-4.
} 
terhadap luas wilayah, jumlah penduduk, atau kebutuhan akan fungsi tertentu, sebagai berikut:

1. Penyediaan RTH berdasarkan luas wilayah.

Proporsi RTH pada wilayah perkotaan adalah minimal 30\% dari luas wilayah, yang terdiri dari 20\% RTH publik dan 10\% RTH privat. Proporsi tersebut dinilai sebagai ukuran minimal yang dibutuhkan untuk keseimbangan ekosistem kota, termasuk sistem hidrologi, mikroklimat, maupun sistem ekologis lainnya, terutama dalam meningkatkan ketersediaan udara bersih yang diperlukan masyarakat serta meningkatkan nilai estetis kota.

2. Penyediaan RTH berdasarkan jumlah penduduk.

Penghitungan kebutuhan dilakukan dengan mengalikan jumlah penduduk yang dilayani dengan standar luas RTH per kapita sesuai peraturan yang berlaku.

3. Penyediaan RTH berdasarkan kebutuhan fungsi tertentu.

Fungsi tertentu yang dimaksud di sini antara lain adalah untuk perlindungan atau pengamanan sarana dan prasarana, misalnya perlindungan kelestarian sumber daya alam, pengamanan pejalan kaki, serta membatasi perkembangan dalam penggunaan lahan agar fungsi utamanya tidak teganggu. RTH dalam kategori ini meliputi jalur hijau sempadan rel kereta api, jalur hijau jaringan listrik tegangan tinggi, RTH sempadan sungai, RTH sempadan pantai, dan RTH pengaman sumber air baku/mata air.

Peraturan Daerah Kota Bandung Nomor 7 Tahun 2011 Tentang Pengelolaan Ruang Terbuka Hijau menyebutkan kewajiban pihak Pemerintah Daerah untuk melakukan pengelolaan ruang terbuka hijau (RTH) dalam rangka menjaga keberadaan dan keberlangsungan RTH. Pengelolaan RTH dilakukan berlandaskan pada asas manfaat, selaras, seimbang, terpadu, keberlanjutan, keadilan, perlindungan, dan kepastian hukum.

Pengaturan pengelolaan RTH dimaksudkan untuk memberikan pedoman dan arahan dalam rangka tertib pengelolaan RTH, serta menyelenggarakan 
pengelolaan RTH secara secara terencana, sistematis, dan terpadu. Pengaturan tersebut juga bertujuan menjamin kepastian hukum dalam menjaga dan melindungi ketersediaan RTH dari alih fungsi lahan serta meningkatkan peran dan tanggung jawab aparatur dan masyarakat dalam mengelola RTH.

Tujuan pengelolaan RTH adalah sebagai berikut:

1. Menjaga keberadaan dan keberlangsungan RTH yang telah ditetapkan sesuai dengan peraturan perundang-undangan;

2. Menjaga keserasian dan keseimbangan ekosistem lingkungan perkotaan;

3. Mewujudkan keseimbangan antara lingkungan alam dan lingkungan buatan di perkotaan;

4. Meningkatkan kualitas lingkungan perkotaan yang sehat, indah, bersih, aman dan nyaman; dan

5. Meningkatkan optimalisasi pemanfaatan RTH.

Pengelolaan RTH diarahkan untuk meningkatkan fungsinya, baik fungsi ekologis, sosial budaya, ekonomi, dan estetika, sebagai berikut ${ }^{6}$ :

1. Fungsi Ekologis, terdiri dari:

- pengamanan keberadaan kawasan lindung perkotaan;

- tempat perlindungan plasma nutfah dan keanekaragaman hayati;

- pengendali pencemaran dan kerusakan tanah, air dan udara pengendali tata air.

2. Fungsi Sosial dan Budaya, terdiri dari:

- sarana bagi warga kota untuk berinteraksi;

- tempat rekreasi;

- sarana pengembangan budaya daerah;

- sarana peningkatan kreativitas dan produktivitas warga kota sarana pendidikan, penelitian dan pelatihan.

3. Fungsi Ekonomi, terdiri dari:

- sarana ekonomi dalam rangka transaksi komoditas produktif;

${ }^{6}$ Id., hlm. 2-24. 
- sarana dalam rangka penambahan nilai dari lingkungan.

4. Fungsi Estetika, terdiri dari:

- sarana dalam rangka meningkatkan kenyamanan dan keindahan lingkungan;

- sarana dalam rangka meningkatkan harmonisasi dan keseimbangan antara ruang terbangun dan ruang tidak terbangun.

Peningkatan fungsi RTH sebagaimana tersebut di atas harus memberikan manfaat bagi masyarakat di daerah yang mencakup:

1. Manfaat langsung yang bersifat nyata (tangible) dan cepat, dalam bentuk keindahan (estetika) dan kenyamanan, sarana penelitian, pendidikan dan penyuluhan, sarana rekreasi aktif dan pasif;

2. Sarana aktivitas sosial bagi warga kota, serta sarana ruang evakuasi untuk keadaan darurat; dan

3. Manfaat tidak langsung yang berjangka panjang dan bersifat tidak nyata (intangible), yaitu persediaan cadangan air tanah, pengendali polusi udara, tanah dan air, serta penyeimbang ekosistem kota.

Pengelolaan RTH merupakan bagian yang tidak terpisahkan dari dokumen perencanaan penataan ruang daerah, dengan ruang lingkup mencakup perencanaan pemanfaatan RTH, pelaksanaan, pengawasan, pengendalian, dan evaluasi. Objek pengelolaaan RTH yang dimaksud di sini meliputi seluruh RTH yang ada dalam lingkup wilayah Kota Bandung. Perencanaan pemanfaatan RTH meliputi kebijakan penyusunan master plan, kebijakan penetapan tipologi RTH dan jenis RTH, kebijakan penyusunan desain teknis, kebijakan penyusunan estimasi pembiayaan sesuai dengan besaran dan jenis RTH, dan penjadwalan.

Peran serta masyarakat dalam proses pengambilan keputusan dapat dibedakan berdasarkan sifatnya, yaitu yang bersifat konsultatif dan bersifat kemitraan. Dalam peran serta masyarakat dengan pola hubungan konsultatif antara pihak pejabat pengambil keputusan dengan kelompok masyarakat yang berkepentingan, anggota-anggota masyarakatnya mempunyai hak untuk didengar 
pendapatnya dan untuk diberi tahu, dimana keputusan terakhir tetap berada di tangan pejabat pembuat keputusan tersebut. Sedang dalam konteks peran serta masyarakat yang bersifat kemitraan, pejabat pembuat keputusan dan anggotaanggota masyarakat merupakan mitra yang relatif sejajar kedudukannya. Mereka bersama-sama membahas masalah, mencari alternatif pemecahan masalah dan membahas keputusan. Karenanya, peran serta masyarakat tidak saja digunakan sebagai sarana untuk mencapai tujuan, tetapi juga digunakan sebagai tujuan (participation is an end itself) 7 .

Masyarakat dalam Peraturan Pemerintah Nomor 68 Tahun 2010 tentang Bentuk dan Tata Cara Peran Masyarakat Dalam Penataan Ruang adalah orang perseorangan, kelompok orang termasuk masyarakat hukum adat, korporasi, dan/atau pemangku kepentingan non pemerintah lain dalam penataan ruang. Peran masyarakat diartikan sebagai partisipasi aktif masyarakat dalam perencanaan tata ruang, pemanfaatan ruang, dan pengendalian pemanfaatan ruang. Bentuk peran masyarakat adalah kegiatan/aktivitas yang dilakukan masyarakat dalam perencanaan tata ruang, pemanfaatan ruang, dan pengendalian pemanfaatan ruang.

Peran serta masyarakat dapat dipandang (sebagai suatu upaya) untuk membantu Negara dan lembaga-lembaganya guna melaksanakan tugas dengan cara yang lebih dapat diterima dan berhasil guna. Peran serta masyarakat ini mensyaratkan pemberian informasi kepada masyarakat dengan cara yang berhasil guna dan berdaya guna. Untuk itu, hal yang perlu diperhatikan diantaranya:

1. Kepastian penerimaan informasi;

2. Informasi lintas batas (transfrontier information) terutama berkaitan dengan dampak kegiatan pada daerah perbatasan termasuk batas Negara;

3. Informasi tepat waktu (timely information);

4. Informasi lengkap (comprehensive information); dan

5. Informasi yang dapat dipahami (comprehensible information).

7 Departemen Kimpraswil, Pedoman Pelibatan Masyarakat dalam Pemanfaatan Ruang, hlm. 3-4, Jakarta, 2001. 


\section{Bentuk Peran Serta Masyarakat Dalam Pengelolaan Ruang Terbuka Hijau Di Kota Bandung}

Penaatan ruang pada dasarnya mengatur kegiatan masyarakat dalam ruang. Dalam hal ini, masyarakat tidak hanya merupakan pihak yang mendapatkan manfaat dari penataan ruang, namun juga merupakan pihak yang memiliki andil terhadap penataan ruang wilayahnya. Masyarakat memiliki hak dan kewajiban untuk menentukan kualitas ruang yang ditinggalinya. Empat dasar pemikiran bagi peran serta masyarakat adalah ${ }^{8}$ :

1. Memberi informasi kepada pemerintah. Peran serta masyarakat ini terutama akan menambah perbendaharaan pengetahuan pemerintah mengenai suatu aspek tertentu yang diperoleh dari pengetahuan khusus masyarakat itu sendiri maupun dari para ahli yang dimintai pendapat oleh masyarakat. Peran serta ini sangat diperlukan untuk memberi masukan kepada pemerintah tentang masalah yang dapat ditimbulkan oleh suatu rencana tindakan pemerintah, termasuk berbagai kepentingan yang dapat terkena tindakan tersebut yang perlu diperhatikan dalam proses pengambilan keputusan, sehingga dapat meningkatkan kualitas keputusan dan tindakan-tindakan yang diambil oleh pemerintah dan lembaga-lembaganya menyangkut rencana tertentu seperti untuk melindungi lingkungan hidup, termasuk tentunya penetapan RTRW.

2. Meningkatkan kesediaan masyarakat untuk menerima keputusan. Warga masyarakat yang telah memperoleh kesempatan untuk berperan serta dalam proses pengambilan keputusan dan tidak dihadapkan pada suatu fait accompli, akan cenderung memiliki kesediaan yang lebih besar untuk menerima dan menyesuaikan diri dengan keputusan tersebut. Lebih penting lagi ialah bahwa peran serta masyarakat dalam proses pengambilan keputusan akan mengurangi kemungkinan timbulnya berbagai pertentangan (konflik), dengan pengertian bahwa peran serta masyarakat dilaksanakan pada saat yang tepat. Perlu dicatat, bahwa keputusan tidak pernah memuaskan semua kepentingan

${ }^{8}$ A.M. Yunus Wahid, 2014, Pengantar Hukum Tata Ruang, Prenadamedia Group, Jakarta, hlm. 176. 
dan semua golongan warga masyarakat, tetapi kesediaan masyarakat untuk menerima keputusan pemerintah dapat ditingkatkan.

3. Membantu perlindungan hukum. Apabila suatu keputusan akhir, memperhatikan keberatan-keberatan (termasuk saran-saran) yang diajukan oleh masyarakat selama proses pengambilan keputusan berlangsung, maka dalam banyak hal tidak akan ada keperluan untuk mengajukan perkara ke pengadilan. Selanjutnya dikemukakan, bahwa apabila sebuah keputusan dapat mempunyai konsekuensi begitu jauh, maka sangat diharapkan bahwa setiap orang yang terkena akibat keputusan itu perlu diberitahukan dan diberi kesempatan untuk mengajukan keberatan sebelum keputusan itu diambil.

4. Mendemokratisasikan pengambilan keputusan. Sehubungan dengan peran serta masyarakat ini, ada yang berpendapat bahwa dalam pemerintahan dengan sistem perwakilan, hak untuk melaksanakan kekuasaan ada pada wakil-wakil rakyat yang dipilih oleh rakyat, sehingga tidak ada keharusan adanya bentuk-bentuk dari peran serta masyarakat karena wakil-wakil rakyat itu bertindak untuk kepentingan rakyat. Argumentasi lain, bahwa dalam sistem perwakilan, peran serta masyarakat dalam proses pengambilan keputusan administratif dapat menimbulkan masalah keabsahan demokrasi, karena warga masyarakat, kelompok atau organisasi yang turut serta dalam proses pengambilan keputusan tersebut, tidak dipilih atau diangkat secara resmi.

Peran masyarakat dalam kegiatan penataan ruang ini juga telah diamanatkan dalam Undang-Undang Nomor 26 Tahun 2007 tentang Penataan Ruang yang selanjutnya diatur dalam Peraturan Pemerintah Nomor 68 Tahun 2010 tentang Bentuk dan Tata Cara Peran Masyarakat dalam Penataan Ruang.

Tujuan pengaturan bentuk dan tata cara peran masyarakat dalam penataan ruang adalah:

1. menjamin terlaksananya hak dan kewajiban masyarakat di bidang penataan ruang sesuai dengan ketentuan peraturan perundang-undangan;

2. mendorong peran masyarakat dalam penataan ruang; 
3. menciptakan masyarakat yang ikut bertanggung jawab dalam penataan ruang;

4. mewujudkan pelaksanaan penataan ruang yang transparan, efektif, akuntabel, dan berkualitas; dan

5. meningkatkan kualitas pelayanan dan pengambilan kebijakan penataan ruang.

\section{Hak Masyarakat}

Dalam kegiatan penataan ruang, masyarakat memiliki hak untuk:

1. mendapatkan informasi dan akses informasi tentang pemanfaatan ruang melalui media komunikasi;

2. menerima sosialisasi rencana tata ruang yang telah ditetapkan;

3. melaksanakan pemanfaatan ruang sesuai peruntukannya yang telah ditetapkan dalam rencana tata ruang;

4. memberikan tanggapan dan masukan kepada pemerintah daerah mengenai pemanfaatan ruang sesuai dengan ketentuan peraturan perundang-undangan;

5. menikmati pertambahan nilai ruang sebagai akibat penataan ruang;

6. memperoleh penggantian yang layak atas kerugian yang timbul akibat pelaksanaan kegiatan pembangunan yang sesuai dengan rencana tata ruang;

7. mengajukan keberatan kepada pejabat berwenang terhadap pembangunan yang tidak sesuai dengan rencana tata ruang di wilayahnya;

8. mengajukan tuntutan pembatalan izin dan penghentian pembangunan yang tidak sesuai dengan rencana tata ruang kepada pejabat berwenang; dan

9. mengajukan gugatan kepada pemerintah dan/atau pemegang izin apabila kegiatan pembangunan tidak sesuai dengan rencana tata ruang.

Dalam mendukung masyarakat untuk mengetahui rencana tata ruang dan peraturan pelaksanaannya, Pemerintah Daerah wajib mengumumkan dan menyebarluaskan RTRW dan peraturan pelaksanaannya. Pengumuman atau penyebarluasan tersebut diselenggarakan melalui penempelan/pemasangan peta rencana tata ruang yang bersangkutan pada tempat-tempat umum dan kantorkantor pelayanan umum, penerbitan booklet atau brosur, pengunggahan pada situs pemerintah daerah, atau pada media cetak dan elektronik lainnya yang sah. 
Masyarakat dapat menikmati manfaat ruang dan/atau pertambahan nilai ruang berupa manfaat ekonomi, sosial, dan lingkungan dilaksanakan atas dasar pemilikan, penguasaan, atau pemberian hak tertentu berdasarkan peraturan perundang-undangan yang berlaku.

Selain itu jika terdapat pelaksanaan kegiatan pembangunan sesuai RTRW yang menyebabkan timbulnya kerugian atas masyarakat, maka masyarakat berhak memperoleh penggantian yang layak yang diselenggarakan secara musyawarah dengan pihak terkait dan tetap memperhatikan kepentingan masyarakat. Namun jika tidak tercapai kesepakatan mengenai penggantian yang layak maka penyelesaiannya dilakukan sesuai dengan peraturan perundangundangan yang berlaku.

\section{Kewajiban Masyarakat}

Dalam kegiatan penataan ruang kota, kewajiban masyarakat adalah sebagai berikut:

1. mentaati rencana tata ruang yang telah ditetapkan;

2. memanfaatkan ruang sesuai dengan izin pemanfaatan ruang dari pejabat yang berwenang;

3. mematuhi ketentuan yang ditetapkan dalam persyaratan izin pemanfaatan ruang; dan

4. memberikan akses terhadap kawasan yang oleh ketentuan peraturan perundang-undangan dinyatakan sebagai milik umum.

Sementara itu pelaksanaan kewajiban masyarakat dalam penataan ruang dilaksanakan dengan mematuhi dan menerapkan kriteria, kaidah, baku mutu, dan aturan-aturan penataan ruang yang ditetapkan sesuai dengan peraturan perundang-undangan yang berlaku. Kaidah dan aturan pemanfaatan ruang yang dipraktekkan masyarakat secara turun temurun dapat diterapkan sepanjang memperhatikan faktor-faktor daya dukung lingkungan, estetika lingkungan, lokasi, dan struktur pemanfaatan ruang serta dapat menjamin pemanfaatan ruang yang serasi, selaras dan seimbang. 


\section{Bentuk dan Tata Cara Peran masyarakat}

Bentuk dan tata cara peran masyarakat dalam kegiatan penataan ruang sifatnya kontekstual, tergantung pada tingkat dan proses kegiatan penataan ruang (perencanaan, pemanfaatan dan pengendalian pemanfaatan ruang). Pelibatan masyarakat dalam kegiatan penataan ruang setidaknya memperhatikan hal berikut:

1. Masyarakat yang terlibat dan dilibatkan harus mewakili semua kelompok kepentingan dengan komposisi yang proporsional termasuk juga kepentingan kelompok yang terpinggirkan;

2. Penentuan masyarakat yang terlibat dan dilibatkan dilakukan secara acak dengan melakukan analisis stakeholder berdasarkan kriteria sebagaimana telah disebutkan sebelumnya.

Bentuk peran masyarakat dalam perencanaan tata ruang menurut Pasal 6 Peraturan Pemerintah Nomor 68 Tahun 2010 tentang Bentuk dan Tata Cara Peran Masyarakat Dalam Penataan Ruang, berupa:

1. Masukan mengenai persiapan penyusunan rencana tata ruang, penentuan arah pengembangan wilayah atau kawasan, pengidentifikasian potensi dan masalah pembangunan wilayah atau kawasan, perumusan konsepsi rencana tata ruang dan/atau penetapan rencana tata ruang.

2. Kerja sama dengan Pemerintah, pemerintah daerah, dan/atau unsur masyarakat dalam perencanaan tata ruang.

Dalam perencanaan tata ruang, bentuk peran masyarakat dapat berupa masukan mengenai beberapa aspek dan kerjasama dengan Pemerintah Daerah dan/atau sesama unsur masyarakat dalam perencanaan tata ruang. Masukan dari masyarakat dalam perencanaan tata ruang adalah mengenai aspek-aspek sebagai berikut:

1. persiapan penyusunan rencana tata ruang;

2. penentuan arah pengembangan wilayah atau kawasan;

3. pengidentifikasian potensi dan masalah pembangunan wilayah atau kawasan; 
4. perumusan konsepsi rencana tata ruang; dan/atau

5. penetapan rencana tata ruang.

Bentuk peran masyarakat dalam pemanfaatan ruang menurut Pasal 8 Peraturan Pemerintah Nomor 68 Tahun 2010 dapat berupa:

1. masukan mengenai kebijakan pemanfaatan ruang;

2. kerja sama dengan Pemerintah, Pemerintah Daerah, dan/atau sesama unsur masyarakat dalam pemanfaatan ruang;

3. kegiatan memanfaatkan ruang yang sesuai dengan kearifan lokal dan rencana tata ruang yang telah ditetapkan;

4. peningkatan efisiensi, efektivitas, dan keserasian dalam pemanfaatan ruang darat, ruang laut, ruang udara, dan ruang di dalam bumi dengan memperhatikan kearifan lokal serta sesuai dengan ketentuan peraturan perundang-undangan;

5. kegiatan menjaga kepentingan pertahanan dan keamanan serta memelihara dan meningkatkan kelestarian fungsi lingkungan hidup dan sumber daya alam; dan

6. kegiatan investasi dalam pemanfaatan ruang sesuai dengan ketentuan peraturan perundang-undangan.

Peran masyarakat dalam pemanfaatan ruang kota dapat berbentuk:

1. masukan mengenai kebijakan pemanfaatan ruang;

2. kerjasama dengan Pemerintah Daerah dan/atau sesama unsur masyarakat dalam pemanfaatan ruang;

3. kegiatan memanfaatkan ruang yang sesuai dengan kearifan lokal dan rencana tata ruang yang telah ditetapkan;

4. peningkatan efisiensi, efektivitas, dan keserasian dalam pemanfaatan ruang darat, ruang udara, dan ruang di dalam bumi dengan memperhatikan kearifan lokal serta sesuai dengan ketentuan peraturan perundang-undangan; 
5. kegiatan menjaga kepentingan pertahanan dan keamanan serta memelihara dan meningkatkan kelestarian fungsi lingkungan hidup dan sumber daya alam; dan

6. kegiatan investasi dalam pemanfaatan ruang sesuai dengan ketentuan peraturan perundang-undangan.

Peran masyarakat dalam pengelolaan RTH diantaranya:

1. Menjaga keberadaan RTH dengan cara:
a) Tidak membangun pada jalur sempadan sungai;
b) Tidak mengubah fungsi taman yang ada; dan
c) Tidak menebang pohon pada jalur hijau sempadan jalan.

2. Memelihara RTH pada Kawasan Perumahan;

3. Turut mengawasi proses pemeliharaan dan keberadaan RTH dengan memberi masukan kepada instansi pengelola jika terjadi penyimpangan penggunaan RTH;

4. Menyediakan lahan untuk penyelenggaraan RTH;

5. Memberikan bantuan dalam mengidentifikasi komponen RTH yang ada maupun yang potensial dikembangkan; dan

6. Memberikan informasi, saran, pertimbangan atau pendapat dalam penyelenggaraan RTH

Bentuk peran masyarakat dalam pengendalian pemanfaatan ruang menurut Pasal 9 Peraturan Pemerintah Nomor 68 Tahun 2010 tentang Bentuk dan Tata Cara Peran Masyarakat Dalam Penataan Ruang dapat berupa:

1. masukan terkait arahan dan/atau peraturan zonasi, perizinan, pemberian insentif dan disinsentif serta pengenaan sanksi;

2. keikutsertaan dalam memantau dan mengawasi pelaksanaan rencana tata ruang yang telah ditetapkan;

3. pelaporan kepada instansi dan/atau pejabat yang berwenang dalam hal menemukan dugaan penyimpangan atau pelanggaran kegiatan pemanfaatan ruang yang melanggar rencana tata ruang yang telah ditetapkan; dan

4. pengajuan keberatan terhadap keputusan pejabat yang berwenang terhadap pembangunan yang dianggap tidak sesuai dengan rencana tata ruang. 
Sedangkan peran masyarakat dalam pengendalian pemanfaatan ruang, dapat berbentuk:

1. masukan terkait arahan dan/atau peraturan zonasi, perizinan, pemberian insentif dan disinsentif serta pengenaan sanksi;

2. keikutsertaan dalam memantau dan mengawasi pelaksanaan rencana tata ruang yang telah ditetapkan.

Masyarakat kota Bandung dapat berperan serta dalam pembangunan RTH melalui tiga jenis bentuk partisipasi, sebagai berikut:

1) Komunitas Hijau, yaitu melalui pembentukan kegiatan, panitia, atau kelompok hijau yang akan mengelola RTH secara swadaya. Kegiatan yang dapat diikuti antara lain: inventarisasi potensi lahan untuk RTH, konfirmasi kondisi lapangan; serta pemeliharaan jangka panjang secara swadaya dalam skala lingkungan.

2) Perusahaan, yaitu melalui pembentukan program peduli lingkungan dan masyarakat (corporate social responsibility). Kegiatan-kegiatan yang dapat melibatkan pihak perusahaan antara lain: bantuan pengadaan lahan, melalui hibah lahan perusahaan untuk RTH; bantuan pengadaan bibit tanaman; bantuan dana kegiatan sosialisasi, kampanye, dan pengabdian masyarakat; serta pemeliharaan dalam jangka panjang.

3) Pribadi/privat, antara lain melalui:

a) pengadaan RTH pekarangan, pengadaan (atau mempertahankan) taman makam keluarga;

b) serta penghijauan skala bangunan seperti vertical garden dan roofgarden.

Upaya Pemerintah dalam rangka Mendorong Peran Serta Masyarakat di Kota Bandung

Pengelolaan RTH di kota Bandung melibatkan berbagai dinas dalam pemerintahan kota. Dinas-dinas yang terkait antara lain BAPPEDA Kota Bandung, Dinas Tata Ruang dan Cipta Karya (Distarcip) Kota Bandung, Dinas Pemakaman 
dan Pertamanan (DPP) Kota Bandung, dan Dinas Pengelolaan keuangan dan Aset Daerah (DPKAD) Kota Bandung.

Tugas dan fungsi BAPPEDA dalam pengelolaan RTH ialah merencanakan RTH dalam tata ruang daerah Kota Bandung dan melakukan koordinasi dengan BAPPEDA Provinsi untuk membuat peraturan mengenai tata ruang, insfrastuktur regional, dan pembinaan. BAPPEDA hanya melakukan perencanaan terkait tata ruang secara keseluruhan Kota Bandung. BAPPEDA telah membuat Kajian Masterplan RTH, tetapi hal tersebut hanya sebatas konsep. Untuk implementasi di lapangan dilakukan oleh dinas-dinas terkait. ${ }^{9}$

Peraturan Menteri Pekerjaan Umum Nomor 05 Tahun 2008 Tentang Pedoman Penyediaan dan Pemanfaatan RTH di Kawasan Perkotaan RTH terdiri dari beberapa jenis yang dikelompokkan sesuai dengan tipologinya, sebagaimana terlihat dalam diagram di bawah ini.

Dinas Pemakaman dan Pertamanan (DPP) terlibat langsung dalam mengelola RTH. Pengelolaan dengan cara memberikan pelatihan ke masyarakat yang berhubungan dengan RTH.

Bagan: Tipologi Ruang Terbuka Hijau

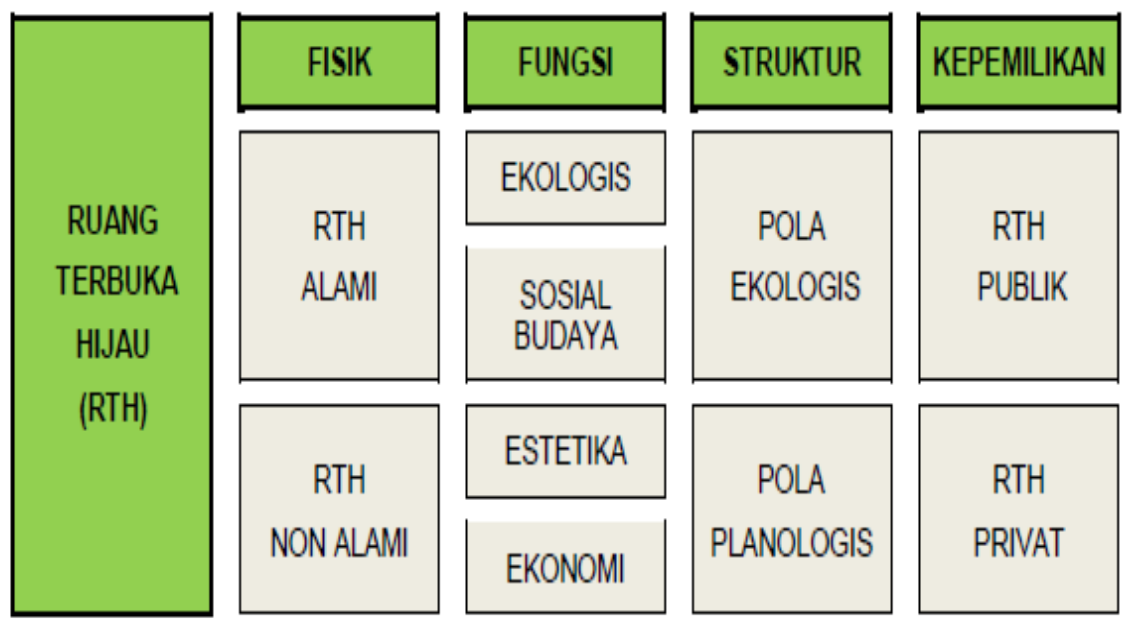

Sumber: Pedoman Penyiapan dan Pemanfaatan RTH di Kawasan Perkotaan

${ }^{9}$ Wawancara dengan Bapak Andri, Bagian Fisik BAPPEDA Kota Bandung. 
Pemeliharaan RTH Kota Bandung yang dilakukan DPP sangat ditunjang dari APBD. Tetapi seringkali dana yang dikeluarkan tidak cukup untuk pemeliharaan RTH di Kota Bandung sehingga perlu adanya bantuan dari pihak swasta. Saat ini Pemerintah Kota Bandung mewajibkan pihak swasta mengelola RTH yang ada di sekitar wilayahnya menggunakan dana CSR. Diharapkan kebutuhan untuk pemeliharaan RTH di Kota Bandung dapat dipenuhi dengan bantuan dana tersebut. Pemerintah Kota Bandung juga merencanakan pembuatan taman tematik di seluruh wilayah Kota Bandung seperti misalnya Taman Maluku yang akan dijadikan Taman Lansia Gaul, Taman Cikapayang yang akan dijadikan Taman Musik, hingga Taman Sukajadi yang akan dijadikan sebagai Taman Lampion. ${ }^{10}$

Dalam Ruang Terbuka Hijau, Distarcip memiliki kewenangan melakukan perencanaan RTH di Perumahan. Distarcip membuat ketentuan mengenai kewajiban kepada setiap komplek untuk memberikan 40\% dari lahan komplek untuk RTH. Apabila pihak developer tidak memenuhi aturan tersebut maka izin untuk membuat komplek tidak akan dikeluarkan. ${ }^{11}$

DPKAD memiliki kewenangan untuk membeli lahan untuk dijadikan RTH. Biasanya lahan yang akan dibeli sebelumnya telah direncanakan oleh Bappeda Kota Bandung sehingga DPKAD akan langsung berkoordinasi dengan Bappeda terkait tempat-tempat atau wilayah-wilayah yang akan dijadikan RTH. Pembelian lahan untuk RTH tersebut disesuaikan dengan Peraturan Pemerintah Nomor 6 Tahun 2006 tentang Pengelolaan Barang Milik Negara/Daerah. Lahan-lahan yang sudah dibeli oleh DPKAD kemudian digunakan sesuai dengan apa yang direncanakan oleh Bappeda Kota Bandung. Pemanfaatan lahan oleh Pemerintah Daerah dapat digunakan untuk sewa, bangun guna serah, pinjam pakai, serta kerjasama pemanfaatan. Dalam pemanfaatan lahan tersebut masyarakat dapat ikut berpartisipasi. Di Kota Bandung banyak masyarakat yang menyewa lahan kepada Pemerintah Daerah. Misalnya saja di sepanjang jalan Dipati Ukur dimana

10 Wawancara dengan Ibu Rike, Bagian Pertamanan DPD Kota Bandung

11 Wawancara dengan Bapak Hendy, Pelayanan Informasi Rencana Kota Distarcip Kota Bandung 
lahan di wilayah tersebut disewa oleh masyarakat untuk dijadikan tempat tinggal hingga gedung perkantoran. Begitu pula dengan Sasana Budaya Ganesha (Sabuga) dimana lahan tersebut merupakan milik Pemerintah Daerah dan disewa oleh pihak lain, yakni ITB. Perjanjian yang dilakukan untuk sewa menyewa lahan ini merupakan sewa -menyewa biasa dengan jangka waktu 5 tahun. Setelah jangka waktu habis, apabila pihak penyewa masih ingin menggunakan lahan milik pemerintah, maka pihak penyewa harus memperpanjang perjanjian sewamenyewa tersebut. Tidak ada mekanisme pemberian insentif untuk pemanfaatan lahan karena di dalam Peraturan Daerah juga belum diatur mengenai hal tersebut. Untuk mendorong peran serta masyarakat, Pemerintah Daerah berkewajiban melaksanakan standar pelayanan minimal dalam rangka pelaksanaan peran masyarakat dalam penataan ruang sesuai dengan ketentuan peraturan perundang-undangan. Kewajiban tersebut antara lain:

1. Dalam proses perencanaan tata ruang.

Memberikan informasi dan menyediakan akses informasi kepada masyarakat tentang proses penyusunan dan penetapan rencana tata ruang melalui media komunikasi yang memiliki jangkauan sesuai dengan tingkat rencana, melakukan sosialisasi mengenai perencanaan tata ruang, menyelenggarakan kegiatan untuk menerima masukan dari masyarakat terhadap perencanaan tata ruang, dan memberikan tanggapan kepada masyarakat atas masukan mengenai perencanaan tata ruang sesuai dengan ketentuan peraturan perundangundangan.

2. Dalam pemanfaatan ruang kota.

Memberikan informasi dan menyediakan akses informasi kepada masyarakat tentang pemanfaatan ruang melalui media komunikasi, melakukan sosialisasi rencana tata ruang yang telah ditetapkan, melaksanakan pemanfaatan ruang sesuai peruntukannya yang telah ditetapkan dalam rencana tata ruang, dan memberikan tanggapan kepada masyarakat atas masukan mengenai pemanfaatan ruang sesuai dengan ketentuan peraturan perundang-undangan. 
3. Dalam pengendalian pemanfaatan ruang.

Memberikan informasi dan menyediakan akses informasi kepada masyarakat tentang pengendalian pemanfaatan ruang melalui media komunikasi, melakukan sosialisasi kepada masyarakat mengenai pengendalian pemanfaatan ruang, memberikan tanggapan kepada masyarakat atas masukan mengenai arahan dan/atau peraturan zonasi, perizinan, pemberian insentif dan disinsentif, serta pengenaan sanksi sesuai dengan ketentuan peraturan perundang-undangan, dan menyediakan sarana yang memudahkan masyarakat dalam menyampaikan pengaduan atau laporan terhadap dugaan penyimpangan atau pelanggaran kegiatan pemanfaatan ruang yang melanggar rencana tata ruang yang telah ditetapkan.

Selain kewajiban tersebut di atas, dalam kegiatan penataan ruang Pemerintah Daerah mengemban tanggung jawab dalam pembinaan dan pengawasan pelaksanaan peran masyarakat yang dilaksanakan sesuai standar pelayanan minimal. Pembinaan yang dimaksud antara lain meliputi:

1. sosialisasi peraturan perundang-undangan dan pedoman bidang penataan ruang;

2. pemberian bimbingan, supervisi, dan konsultasi pelaksanaan penataan ruang;

3. pengembangan sistem informasi dan komunikasi penataan ruang;

4. penyebarluasan informasi penataan ruang kepada masyarakat; dan

5. pengembangan kesadaran dan tanggung jawab masyarakat.

Upaya peningkatan peran masyarakat juga menjadi tanggung jawab Pemerintah Daerah. Terkait hal tersebut, Pemerintah Daerah perlu membangun sistem informasi dan komunikasi penyelenggaraan penataan ruang yang dapat diakses dengan mudah oleh masyarakat sesuai dengan ketentuan peraturan perundang-undangan. Sistem informasi dan komunikasi ini harus memuat paling sedikit:

1. informasi tentang kebijakan, rencana, dan program penataan ruang yang sedang dan/atau akan dilakukan, dan/atau sudah ditetapkan; 
2. informasi rencana tata ruang yang sudah ditetapkan;

3. informasi arahan pemanfaatan ruang yang berisi indikasi program utama jangka menengah lima tahunan;

4. informasi arahan pengendalian pemanfaatan ruang yang berisi arahan/ ketentuan peraturan zonasi, arahan/ketentuan perizinan, arahan/ketentuan insentif dan disinsentif, serta arahan sanksi;

5. Pembangunan sistem informasi dan komunikasi penataan ruang kota menjadi tanggung jawab Walikota. Adapun SKPD yang bidang tugasnya terkait dengan penataan ruang dapat memberikan fasilitasi pembangunan sistem informasi dan komunikasi di daerah.

Pelibatan masyarakat juga menjadi salah strategi pembangunan RTH Kota Bandung, yang berbentuk:

1) Penyusunan arahan teknis untuk RTH privat berkaitan dengan luas RTH kota keseluruhan, misalnya arahan mengenai penanganan area parkir, lapangan olahraga, posyandu, gedung pemerintahan, sekolah, dan museum.

2) Melakukan kerjasama pembangunan ruang terbuka hijau dengan institusiinstitusi yang memiliki program tanggung jawab dan lingkungan (corporate social responsibility).

3) Melakukan pemetaan para pemangku kebijakan (stakeholders) yang terkait dengan kegiatan peningkatan RTH kota, baik komunitas, forum, maupun individu, agar masing-masing dapat berperan serta secara seimbang dalam pembangunan RTH kota.

4) Menjadikan pembangunan dan pengembangan RTH melibatkan semua unsur masyarakat.

5) Memberikan insentif kepada warga yang bersedia menjadikan seluruh atau sebagian lahan miliknya sebagai lahan RTH, baik publik maupun privat.

6) Memberikan insentif kepada warga yang terlibat dalam berbagai kegiatan penghijauan kota, seperti beasiswa, pengakuan, publikasi, serta lomba/piala. 


\section{Penutup}

Peran serta masyarakat dalam pemanfaatan Ruang Terbuka Hijau tidak lagi hanya mengawasi kebijakan pemerintah, tapi berperan aktif dalam menata dan merawat Ruang Tebuka Hijau yang ada di lingkungannya. Perluasan pengertian masyarakat yang tidak semata-mata pihak yang terkena dampak, tapi juga sebagai kelompok interest dan pressure group membuat peran serta semakin luas dengan ikut melakukan pengelolaan bahkan penambahan Ruang Terbuka Hijau melalui perjanjian dengan pemerintah. Kolaborasi antar warga sangat membantu dalam membuat RTH berfungsi sesuai dengan kebutuhan masyarakat di sekitarnya. Meskipun demikian kesadaran masyarakat terhadap pentingnya RTH masih perlu ditingkatkan karena masih banyak lahan yang merupakan RTH digunakan untuk aktivitas lain di luar peruntukannya misalnya digunakan sebagai lahan parkir atau berdagang (PKL).

Untuk mendorong peran serta masyarakat dalam pengelolaan Ruang Terbuka Hijau, pemerintah terus melakukan berbagai cara untuk meningkatkan peran serta masyarakat dengan mendorong melakukan kerjasama pembangunan ruang terbuka hijau dengan institusi-institusi yang memiliki program tanggung jawab dan lingkungan (corporate social responsibility) yang menjadikan pembangunan dan pengembangan RTH melibatkan semua unsur masyarakat. Memberikan insentif kepada warga yang bersedia menjadikan seluruh atau sebagian lahan miliknya sebagai lahan RTH, baik publik maupun privat. Memberikan insentif kepada warga yang terlibat dalam berbagai kegiatan penghijauan kota, seperti beasiswa, pengakuan, publikasi, serta lomba/piala.

Pelibatan Masyarakat dalam Pengelolaan dan Penataan RTH mutlak diperlukan, karena itu komunikasi yang intensif antara pemerintah dan para stakeholder lainnya perlu dilakukan. Munculnya komunitas-komunitas yang peduli terhadap Ruang Terbuka Hijau di kota Bandung merupakan suatu fenomena yang dapat dimanfaatkan pemerintah sebagai wadah untuk berkolaborasi dimana 
pemerintah melihat masyarakat sebagai mitra yang sejajar, sehingga mempermudah kerjasama yang dilakukan.

\section{Daftar Pustaka}

Buku:

A.M. Yunus Wahid, Pengantar Hukum Tata Ruang, Prenadamedia Group, Jakarta, 2014.

Budihardjo, Eko dan Sujarto, Djoko, Kota Berkelanjutan, PT. Alumni, Bandung.

Hasni, Hukum Penataan Ruang dan Penatagunaan Tanah, Rajawali Pers, Jakarta, 2008

Hans Kelsen, Hukum dan Logika (Essays in Legal and Moral Philosophy), diterjemahkan oleh B. Arief Sidharta, Alumni, cetakan kedua, Bandung, 2002.

Nirwono Joga, Gerakan Kota Hijau, PT. Gramedia Pustaka Utama, 2013.

Maria S.W Sumardjono, Pedoman Pembuatan Usulan Penelitian, makalah pada Seminar tentang Metodologi Penelitian bagi Dosen Fakultas Hukum Universitas Gadjah Mada, 12 April, Yogyakarta, 1989.

Ronny Hanitijo, Metodologi Penelitian Hukum dan Jurimetri, Ghalia Indonesia, cetakan kedua, Jakarta, 1988.

Sunaryati Hartono, Penelitian Hukum di Indonesia Pada Akhir Abad ke-20, Penerbit Alumni, Bandung, 1994

Sudikno Mertokusumo, Penemuan Hukum: Sebuah Pengantar, Liberty, edisi pertama, Yogyakarta, 1996

\section{Undang-Undang:}

Undang-Undang Nomor 26 Tahun 2007 Tentang Penataan Ruang Peraturan Daerah Kota Bandung Nomor 18 Tahun 2011 Tentang Rencana Tata Ruang Wilayah Kota Bandung Tahun 2011-2031

Peraturan Menteri Pekerjaan Umum Nomor 05 Tahun 2008 Tentang Pedoman Penyediaan dan Pemanfaatan Ruang Terbuka Hijau di Kawasan Perkotaan

Peraturan Daerah Kota Bandung Nomor 7 Tahun 2011 Tentang Pengelolaan Ruang Terbuka Hijau

Peraturan Pemerintah Nomor 68 Tahun 2010 tentang Bentuk dan Tata Cara Peran Masyarakat Dalam Penataan Ruang

BAPPEDA, Laporan Master Plan Ruang Terbuka Hijau Kota Bandung 2012-2032, Bandung

Departemen Kimpraswil, Pedoman Pelibatan Masyarakat dalam Pemanfaatan Ruang, Jakarta, 2001

\section{Wawancara:}

Wawancara dengan Bapak Andri, Bagian Fisik BAPPEDA Kota Bandung Wawancara dengan Ibu Rila, Bagian Ruang Terbuka Hijau DPP Kota Bandung 
Wawancara dengan Ibu Rike, Bagian Pertamanan DPD Kota Bandung Wawancara dengan Bapak Hendy, Pelayanan Informasi Rencana Kota Distarcip Kota Bandung

Wawancara dengan Bapak Deni, Bagian Kepala Seksi Pengamanan dan Penanganan Sengketa DPKAD Kota Bandung

Wawancara dengan Kandi Sekarwulan, Penggagas Komunitas Sahabat Kota

Lain-lain:

BAPPEDA, Laporan Master Plan Ruang Terbuka Hijau Kota Bandung 2012-2032, Bandung

Departemen Kimpraswil, Pedoman Pelibatan Masyarakat dalam Pemanfaatan Ruang, Jakarta, 2001 